experiments, and Miss C. J. Blamire and Mrs. P. K. Brown in the laboratory work. Dr. P. J. Chapple carried out some of the preliminary experiments on strain H.W., and Drs. H. G. Pereira and A. T. Roden on strain M.R.

\section{REFERENCES}

Fiala, M., and Kenny, G. E. (1966). 7. Bact., 92, 1710. Hamre, D., Connelly, A. P., and Procknow, J. J. (1966). Amer. 7. Epidem., 83, 238.

Higgins, P. G. (1966). Mth Bull. Minist. Hlth Lab. Serv., 25, 283.

Hoorn, B. (1966). Acta path. microbiol. scand., 66, Suppl. No. 183.

Hoorn, B., and Tyrrell, D. A. J. (1966). Arch. ges. Virusforsch., 18, 210
Kendall, E. J. C., Bynoe, M. L., and Tyrrell, D. A. J. (1962). Brit. med. 7., 2,82 .

Medical Research Council Working Party (1965). Brit. med. 7., 2, 319. Phillips, C. A., Melnick, J. L., and Grim, C. A. (1965). Proc. Soc. exp. Biol. (N.Y.), 119, 843.

Stott. E. J., and Tyrrell, D. A. J. (1968). Arch. ges. Virusforsch., 22, 417 Tyrrell, D. A. J. (1963). Amer. Rev. resp. Dis., 88, Part 2, p. 128.

Tyrrell D. A. J. (1967). Proceedings of P.A.H. Conference P. 659. First International Conference on Vaccines against Viral and First International Conference on Vaccines against Viral and Tyrrell, D. A. J., and Almeida, J. D. (1968). Arch. ges. Virusforsch. In press.

Tyrrell, D. A. J., and Blamire, C. J. (1967). Brit. f. exp. Path., 48, 217. Tyrrell, D. A. J., and Bynoe, M. L. (1961). Brit. med. F., 1, 393.

Tyrrell, D. A. J. and Bynoe, M. L. (1965). Brit. med. F., 1, 1467

Tyrrell, D. A. J., and Bynoe, M. L. (1966). Lancet, 1, 76.

\title{
Necrotic Cervicitis Due to Primary Infection with the Virus of Herpes Simplex
}

\author{
R. R. WILLCOX,* M.D.
}

[With Special Plate facing Page 602]

Since July 1965 I have encountered in London six cases of extremely severe and necrotic cervicitis, the whitish appearances of which were strikingly similar. The condition in the first case was unfamiliar, but with subsequent cases evidence has been assembled which strongly suggests that the cervicitis is due to the virus of herpes simplex.

\section{Present Series}

Case Material.-The basic data concerning the six cases are given in Table $\mathrm{I}$. The women were aged 20-28 years (average 23.3 years), four were white and two Negro, and three were single and three married. All were attending the venereal diseases clinic for the first time and none gave a history of any previous venereal infection.

\begin{tabular}{|c|c|c|c|c|c|}
\hline $\begin{array}{l}\text { Case } \\
\text { No. }\end{array}$ & $\begin{array}{c}\text { Age in } \\
\text { Years }\end{array}$ & Race & $\begin{array}{c}\text { Married } \\
\text { or Single }\end{array}$ & Occupation & $\begin{array}{c}\text { Previous } \\
\text { History of } \\
\text { Venereal } \\
\text { Disease }\end{array}$ \\
\hline $\begin{array}{l}1 \\
2 \\
3 \\
4 \\
5 \\
6\end{array}$ & $\begin{array}{l}21 \\
20 \\
23 \\
21 \\
28 \\
27\end{array}$ & $\begin{array}{l}\text { White } \\
\text { White } \\
\text { Negro } \\
\text { Negro } \\
\text { White } \\
\text { White }\end{array}$ & $\begin{array}{l}S \\
\mathbf{S} \\
\mathbf{M} \\
\mathbf{S} \\
\mathrm{M} \\
\mathrm{M}\end{array}$ & $\begin{array}{l}\text { Receptionist } \\
\text { Sales promotion } \\
\text { Canteen assistant } \\
\text { Machinist } \\
\text { Housewife } \\
\text { Public relations }\end{array}$ & $\begin{array}{l}\text { No } \\
\text { No } \\
\text { No } \\
\text { No } \\
\text { No } \\
\text { No }\end{array}$ \\
\hline
\end{tabular}

Symptoms.-The presenting symptoms are given in Table II. All six patients complained of vaginal discharge, four of dysuria, three of local soreness, and four of pain in the lower abdomen, right iliac fossa, or the genitals. In Case 1 the dysuria was severe, and twice daily catheterization had been performed in Spain before the patient decided to fly home to take further advice. The onset was acute or subacute, symptoms having been present for from one to nine days before they attended the clinic.

Findings on Examination.-These are shown in Table III and in the Special Plate. In all cases there was gross cervicitis, from which pieces of dead tissue might separate, leaving a white necrotic core around the os. Pain on touching or moving the cervix was elicited in four cases, and in all six the cervix bled easily. The inguinal lymph nodes were enlarged and tender in only one case. There was some known fever in four cases, but in all except one this was not severe at the time of recording, though it may well have subsided by the time the patients were first seen. In one case it was known to have reached $104^{\circ} \mathrm{F}$. $\left(40^{\circ}\right.$ C. $)$. The presumptive or alternative diagnosis on these cases at the first cervical inspection ranged from gonorrhoea (two cases), salpingitis (two cases), carcinoma of the cervix, leucoplakia, and the effects of cautery.

\begin{tabular}{|c|c|c|c|c|c|}
\hline $\begin{array}{l}\text { Case } \\
\text { No. }\end{array}$ & $\begin{array}{c}\text { Vaginal } \\
\text { Discharge }\end{array}$ & Dysuria & $\begin{array}{l}\text { Local } \\
\text { Soreness }\end{array}$ & Pain & $\begin{array}{l}\text { Duration of } \\
\text { Symptoms }\end{array}$ \\
\hline & Yes & & Yes & $\begin{array}{l}\text { Yes, lower } \\
\text { abdomen }\end{array}$ & 10 days $f$ \\
\hline $\begin{array}{l}2 \\
3 \\
4 \\
5 \\
6\end{array}$ & ", & $\begin{array}{l}", \\
", \\
\text { No }\end{array}$ & $\begin{array}{l}\text { "’ } \\
\text { No } \\
\text { ”, }\end{array}$ & $\begin{array}{ll}\text { ", R.I.F. } \\
\text { ”, genital } \\
\text { No } \\
\text { " }\end{array}$ & $\begin{array}{ll}2 & \\
9 & ” \\
3 & ” \\
4 & ” \\
1 & ”\end{array}$ \\
\hline
\end{tabular}
few days of discharge and dysuria.

\section{TABLE III.-Findings on Examination}

\begin{tabular}{|c|c|c|c|c|c|}
\hline $\begin{array}{l}\text { Case } \\
\text { No. }\end{array}$ & $\begin{array}{l}\text { Cervi- } \\
\text { citis }\end{array}$ & $\begin{array}{l}\text { Pain on } \\
\text { Touching } \\
\text { or Moving } \\
\text { Cervix } \\
\end{array}$ & $\begin{array}{l}\text { Tender } \\
\text { Inguinal } \\
\text { Nodes }\end{array}$ & $\begin{array}{l}\text { Fever } \\
\left({ }^{\circ} \mathrm{F} .\right)\end{array}$ & $\begin{array}{l}\text { Presumptive or } \\
\text { Alternative Diagnosis } \\
\text { at First Clinical } \\
\text { Examination }\end{array}$ \\
\hline 1 & ++ & Yes & No & $\begin{array}{l}99^{\circ}, \text { ? earlier } \\
\text { more so }\end{array}$ & $\begin{array}{l}\text { Gonorrhoea, salpingitis, } \\
\text { effects of cautery }\end{array}$ \\
\hline $\begin{array}{l}2 \\
3 \\
4\end{array}$ & $\begin{array}{l}++ \\
++ \\
++\end{array}$ & ”, & $\begin{array}{l}\text { Yes } \\
\text { No } \\
\text {,y }\end{array}$ & $\begin{array}{l}99^{\circ} \\
\text { No } \\
\end{array}$ & $\begin{array}{l}\text { Salpingitis } \\
\text { Carcinoma of cervix }\end{array}$ \\
\hline$\frac{4}{5}$ & $\begin{array}{l}+t \\
++\end{array}$ & No & $"$, & $\begin{array}{c}98.6^{\circ}, \text { earlier } \\
\text { probably } \\
\text { more so }\end{array}$ & Leucoplakia of cervix \\
\hline 6 & ++ & ", & " & $104^{\circ}$ & Gonorrhoea \\
\hline
\end{tabular}

\section{Investigations}

The results of some of the investigations made on these patients are shown in Table IV. The tests for venereal disease, which included urethral and cervical smears and cultures for gonococci, an examination of a wet specimen of vaginal exudate for trichomonads, a dark-field examination of a cervical speci- 
men for Treponema pallidum, Wassermann reaction, and VDRL or Harris serum test for syphilis, were negative in all cases. A culture of the midstream specimen of urine was sterile in all the four patients tested, and of the three in which general cultures were made from the cervix faecal organisms, Proteus, and Staphylococcus albus were obtained in two and nothing significant in one. The serum was examined by complement-fixation test for lymphogranulo a venereumpsittacosis in three cases, with negative resulr $\mathrm{n}$ two and a positive result in one Negro patient.

\begin{tabular}{|c|c|c|c|c|c|c|c|}
\hline $\begin{array}{l}\text { Case } \\
\text { No. }\end{array}$ & $\begin{array}{c}\text { Tests } \\
\text { for } \\
\text { Venereal } \\
\text { Disease } \\
\end{array}$ & $\begin{array}{l}\text { Urine } \\
\text { Culture }\end{array}$ & $\begin{array}{c}\text { Culture of } \\
\text { Cervical Swab }\end{array}$ & $\begin{array}{l}\text { Cervical } \\
\text { Cytology }\end{array}$ & $\begin{array}{l}\text { L.G.V. } \\
\text { C.F.T. }\end{array}$ & $\left|\begin{array}{c}\text { w.B.c. } \\
\text { per } \\
\text { cu. } \\
\text { mm. }\end{array}\right|$ & $\begin{array}{l}\text { E.S.R. } \\
\text { (mm. } \\
\text { in } \\
1 \mathrm{hr} .)\end{array}$ \\
\hline 1 & Neg. & Sterile & \begin{tabular}{|l|} 
Staph. albus, \\
Proteus, \\
E.coli, \\
Str. faecalis
\end{tabular} & $\begin{array}{l}\text { Too } \\
\text { haemorrhagic }\end{array}$ & Neg. & 5,000 & 22 \\
\hline $\begin{array}{l}2 \\
3\end{array}$ & ", & 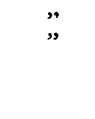 & $\left|\begin{array}{l}\bar{E} \text {. coli, } \\
\text { enterococci, } \\
\text { coagulase- } \\
\text { negative } \\
\text { Staph, albus }\end{array}\right|$ & $\begin{array}{l}\overline{\text { No evidence }} \\
\text { of malignancy }\end{array}$ & $\overrightarrow{\text { Neg. }}$ & $\begin{array}{l}6,000 \\
5,000\end{array}$ & $\begin{array}{l}15 \\
40\end{array}$ \\
\hline 4 & " & - & & $\begin{array}{l}\text { Severe endo- } \\
\text { cervicitis. } \\
\text { Repeat } \\
\text { advised }\end{array}$ & $\begin{array}{c}\text { Pos. } \\
1: 80\end{array}$ & - & 38 \\
\hline 5 & ". & - & - & $\begin{array}{l}\text { aavisea } \\
\text { Severely in- } \\
\text { flamed cells. } \\
\text { Heavily } \\
\text { contaminated } \\
\text { with blood. } \\
\text { Repeat } \\
\text { advised }\end{array}$ & - & - & - \\
\hline 6 & " & Sterile & $\begin{array}{l}\text { No sig. } \\
\text { growth }\end{array}$ & $\begin{array}{l}\text { Too } \\
\text { haemorrhagic }\end{array}$ & - & 4,000 & 41 \\
\hline
\end{tabular}

Routine cervical cytology was done in five cases. One was reported as showing no evidence of malignancy and two of the smears proved to be too haemorrhagic for examination. Two cases showed "severe endocervicitis" or "severely inflamed cells," and a later repeated examination was advised, but in both cases no evidence of malignancy was then found.

The white cell count ranged from 4,000 to 6,000 cells per cu. $\mathrm{mm}$. in all the four patients tested, but the erythrocyte sedimentation rate was consistently raised, with a range of $15-41 \mathrm{~mm}$. in one hour in the five cases so examined.

\section{Treatment, Observation, and Progress}

The treatment given, progress made, and follow-up results are shown in Table V. The first three patients were admitted to hospital and the last three were treated as outpatients; admission was recommended in Case 6 on account of her high fever, but this was refused.

The systemic treatments ranged from procaine penicillin, ampicillin, tetracycline, and sulphadiazine given systemically alone or in combination, and from Penotrane (hydrargaphen) pessaries and jelly, Locan cream, and tetracycline vaginal tablets

TABLB V.-Observation, Treatment, and Progress

\begin{tabular}{|c|c|c|c|c|c|}
\hline $\begin{array}{l}\text { Case } \\
\text { No. }\end{array}$ & $\begin{array}{c}\text { Admis- } \\
\text { sion } \\
\text { to } \\
\text { Hospital } \\
\end{array}$ & $\begin{array}{l}\text { Systemic } \\
\text { Treatment }\end{array}$ & $\begin{array}{l}\text { Local Vaginal } \\
\text { Treatment }\end{array}$ & $\begin{array}{c}\text { Observa- } \\
\text { tion } \\
\text { in } \\
\text { Days }\end{array}$ & $\begin{array}{l}\text { Healing } \\
\text { of Cervix }\end{array}$ \\
\hline 1 & Yes & $\begin{array}{l}\text { Procaine penicil- } \\
\text { lin. Ampicillin }\end{array}$ & Penotrane pessaries & 111 & $\begin{array}{l}\text { Healed in } 16 \\
\text { days }\end{array}$ \\
\hline 2 & , & $\begin{array}{l}\text { Ampicillin. Pro- } \\
\text { caine penicillin. } \\
\text { Tetracycline }\end{array}$ & $\begin{array}{l}\text { Penotrane jelly and } \\
\text { pessaries and } \\
\text { Locan cream }\end{array}$ & 421 & $\begin{array}{c}\text { Healed in } 15 \\
\text { days }\end{array}$ \\
\hline 3 & $"$ & Sulphadiazine & Tetracycline tablets & 237 & $\begin{array}{c}\text { Healed in } 20 \\
\text { days }\end{array}$ \\
\hline 4 & No & Sulphadiazine & $\mathrm{Ni}$ & 30 & $\begin{array}{l}\text { Nearly } \\
\text { healed at } \\
23 \text { days }\end{array}$ \\
\hline 5 & " & Sulphadiazine & Penotrane pessaries & 71 & $\begin{array}{l}\text { Nearly } \\
\text { healed at } \\
16 \text { days }\end{array}$ \\
\hline 6 & Refused & Tetracycline & $\begin{array}{l}\text { Tetracycline vaginal } \\
\text { tablets }\end{array}$ & 59 & $\begin{array}{l}\text { Healed when } \\
\text { seen at } \\
\text { 59th day* }\end{array}$ \\
\hline
\end{tabular}

- No intermediate examination after end of first week. to no treatment locally. The periods of observation have so far ranged from 59 to 421 days.

Apparently the rate of healing of the cervix was not particularly related to the systemic treatment given, though as regards $\underline{w}$ local vaginal medication healing took the longest in the one case in which no local treatment was used. Healing or near $\$$ healing appeared to be slow in the individual case, but wasc observed to have taken place within two to three weeks in most cases. At first a white slough localized around the os, involving the cervical canal; it then seemed to separate, and sometimes some erosive lesions persisted for a while on the vaginal portion of the organ. Final healing was complete with no residual $\frac{\bar{s}}{\sigma}$ lesions.

\section{Evidence to Incriminate Herpes Simplex}

The evidence for believing that the striking picture of $\overrightarrow{\vec{\omega}}$ necrotic cervicitis is due to a primary infection with the virus $\frac{\rho}{\partial}$ of herpes simplex is summarized in Table VI.

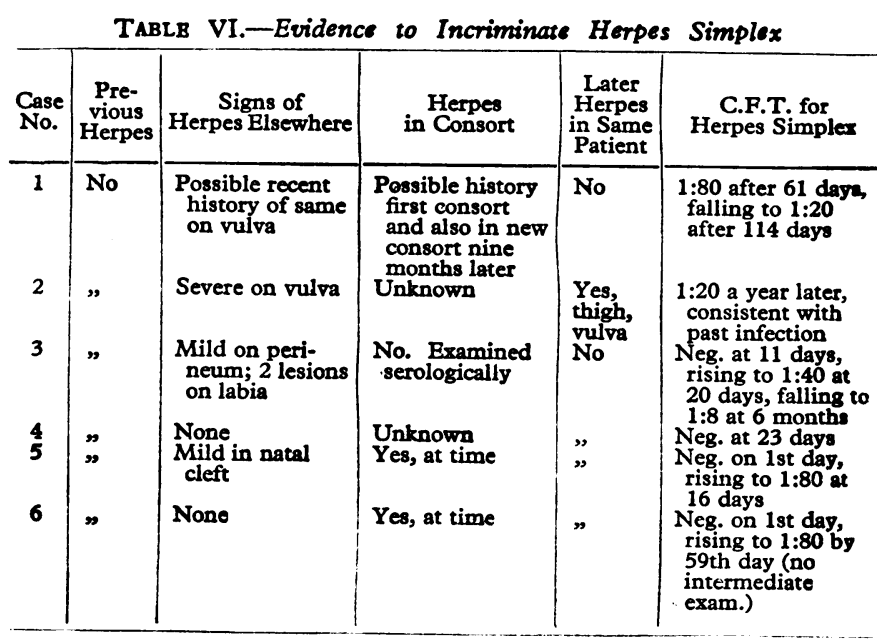

Clinically, four of the patients with cervicitis had or had recently had minute sores elsewhere in the anogenital area consistent with herpes simplex, though only in one case were the lesions severe enough to be classified unmistakably as herpetic. None gave a previous history of herpes. In one patient recurrences of external herpetic lesions were subsequently noted. Severe dysuria was a symptom in other cases of unequivocal vulvar herpes, either due to herpetic lesions within the urinary meatus or near the introitus or due to the irritative effect of $\cong$ urine on the sores. I have encountered two such cases requiring $N$ catheterization, and a third case in which the pain on micturition reduced the woman to tears.

Epidemiologically, two of the male consorts had genital herpes at the time the cervicitis was diagnosed. In one case the consort had "had something," and a later consort of the same patient apparently contracted the condition nine months later. In another case the male was seen with a panticularly severe and painful preputial sore before the female attended with cervicitis. The status of the male was unknown in two cases, but the husband of the remaining patient, who had denied extramarital exposure, was seen and provided no historical, clinical, or serological signs of the condition.

No attempts were made to grow the virus in these cases except rather tardily on the nineteenth day in Case 3, but without success. However, significant immunological evidence was obtained. Complement-fixation tests for herpes simplex were performed in all oases. In three (Cases 3, 5, and 6) the test was negative at the outset but subsequently became positive, rising to a titre of $1: 40$ or $1: 80$ in two cases within 16 to 20 days and had done so in the third patient (Case 6), who was not examined again until the 59th day. In one of these the

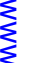


titre subsequently fell. In Case 1 a titre of 1:80 was noted at 61 days, and this had fallen to $1: 20$ at 114 days. In Case 2 the test was not made until a year had elapsed, by which time the titre of 1:20 obtained was reported as consistent with a past infection. In Case 4 the complement-fixation test was still negative at 23 days, shortly after which time she defaulted. However, this could well have become positive later.

During the period during which these cases were encountered a further patient with severe unequivocal vulvar herpes was seen. She was a 21-year-old woman who also developed a high fever of $103.4^{\circ}$ F. $\left(39.7^{\circ}\right.$ C.), drowsiness, and headache; a lumbar puncture was required to exclude complicating encephalitis. Four months later there was a recurrence of the herpes on her vulva. In this case repeated complement-fixation reactions for herpes simplex were negative at $1,2,5,12$, and 21 days from first attendance.

\section{Summary and Conclusions}

Six cases of a strikingly unusual necrotic cervicitis of great severity in young women are described. Symptoms included vaginal discharge in all cases; some had dysuria, which in one case was severe enough to require catheterization; and some complained of lower abdominal pain. The onset was acute or subacute with evidence of fever, which was high in one patient. The affected cervices were white and necrotic, particularly around the os, bled very easily, and were in some cases tender to the touch or on movement. Gonorrhoea, salpingitis, leucoplakia, carcinoma, and the effects of cautery were all at one time considered in the diagnosis.
Tests for gonorrhoea, syphilis, and trichomoniasis were consistently negative. A bacterial swab from the cervix might or might not show faecal organisms; the cervical cytology was unsuitable, requiring the examination to be repeated because the specimen was either too haemorrhagic or contained severely inflamed cells. The white cell count was not raised (range $4,000-6,000 / \mathrm{cu}$. mm.) but a consistent positive finding was a raised sedimentation rate $(15-40 \mathrm{~mm}$. in one hour).

The cervix healed slowly and the white core-like slougb around the cervical os and involving the endocervix persisted usually for more than seven days, but complete healing occurred in the majority of cases during the third week.

The cases indicate that necrotic cervicitis may be associated with other herpetiform lesions in the anogenital area or may exist alone. The male consort may show herpetiform lesions at or before the time the condition is diagnosed in the female.

The pattern of results of the complement-fixation test for herpes simplex in these cases was for the reaction to be negative at the time the cervicitis was severe but to become positive at a titre of $1: 40$ to $1: 80$ in the third week as the cervix was healing. Seropositivity once present may apparently persist at a high level for two or more months, after which time there is a tendency for the titre to fall to a lower level but still to be detectable a year later.

Primary infection with herpes simplex can be a serious sexual hazard for the young woman, resulting sometimes in an acute illness necessitating admission to hospital.

Gratitude is expressed to Professor K. R. Dumbell for kindly undertaking the serological investigations for herpes simplex.

\title{
Translocation of Lippes Loop (The Missing Loop)*
}

\author{
S S. RATNAM,† F.R.C.S., F.R.C.S.ED., F.R.C.s.glASG., M.R.C.o.G. ; J. C. K. YIN, $\ddagger$ M.B., B.S., D.M.R.D
}

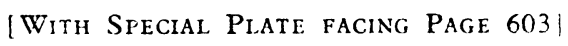

The use of intrauterine contraceptive devices for fertility control is on the increase. At the Second International Conference sponsored by the Population Council in October 1964 it was estimated that more than 100,000 women were wearing the Lippes loop. Since then many more countries have taken part in the international programme for population control, and in some of them the loop has displaced all other methods of family planning. The number of women wearing the loop must be very much greater than that reported in 1964 . Various modifications of the old Grafenberg ring-Hall and Stone, 1962 ; Lippes, 1962 ; Margulies, 1962 ; Birnberg and Burnhill, 1964 -have been made available for mass insertion in national family planning programmes. Of the various forms of plastic devices the Lippes loop was chosen by the Population Council because of the simplicity of its insertion and removal, and the minimal side-effects and complications. The greatest advantage of the devices with a cervical appendage like the spiral and the loop is the simplicity in which their presence and proper position within the uterine cavity can be confirmed. However, the tail

- This study was conducted by the Joint University/Government I.U.C.D. Project Committee. The members of the Committee are : Prof essor
S. H. Tow (chairman), Mr. T. H. Lean, Dr. S. M. Goon, Dr. D. S. H. Tow (chairman), Mr.
Wolfers, Mr. S. S. Ratnam.

t Lecturer, Department of Obstetrics and Gynaecology, University of

‡ Radiologist, General Hospital, Singapore of a Lippes loop may disappear if it works its way into the uterine cavity, myometrium, abdominal cavity, or endocervix; when the loop is expelled without the patient's knowledge ; or when the loop is inserted direct into the peritoneal cavity through a uterine perforation.

Though translocation or uterine perforation has been recorded by many workers (Table I) the incidence reported by those carrying out large-scale insertions has been very low. The incidence for the Lippes loop is stated to be about $0.6 / 1,000$ (Tietze, 1965). However, a study of 8,977 insertions carried out at the Kandang Kerbau Hospital, Singapore, by a Joint University/Government Committee showed an incidence of $0.87 \%$, or $8.7 / 1,000$ - much greater than that reported by other workers. The study included post-partum women who had their babies at the hospital between October 1965 and July 1966. Women who accepted the loop were given the choice of having it before they were discharged from the hospital or on their postnatal visit four to eight weeks later. A total of 3,168 loops were inserted in the immediate post-partum period and 5,809 in the delayed post-partum period (Table II). More than $90 \%$ of the immediate post-partum insertions were performed in the first 48 hours after delivery. All insertions were carried out by doctors who had some experience in gynaecology or who had been specially trained to insert the loops. The patients wire instructed to feel for the nylon threads at frequent 